\title{
Toothache tales: Part 1
}

\author{
M. E. Richardson ${ }^{1}$
}

This selection of literary extracts deals with the subject of toothache from the point of view of the sufferer. Circumstances, effects and remedies, orthodox and otherwise, are described.

Until the last decades of the twentieth century, few individuals went through life without, at some stage, suffering the pangs of toothache. It is hardly surprising therefore, that toothache is a subject commonly referred to in literature particularly of the autobiographical genre.

\section{PHILOSOPHY AND TOOTHACHE}

The philosophy of pain is likely to be of more interest to the philosopher than to the sufferer. According to W. Somerset Maugham ${ }^{1}$ It is curious to notice that when they speak of evil, philosophers so often use toothache as their example. They point out with justice that you cannot feel my toothache. In their sheltered, easy lives, it looks as though this were the only pain that had much afflicted them, and one might almost conclude that with the improvement of American dentistry the whole problem could be conveniently shelved. I have sometimes thought that it would be a very good thing if, before philosophers were granted the degrees that will enable them to impart their wisdom to the young, they had to spend a year in social service in the slums of a great city or earn their living by manual labour. If they had ever seen a child die of meningitis they would face some of the problems that concern them with other eyes.'

\footnotetext{
${ }^{1}$ Margaret E Richardson,

Correspondence to: Associate Specialist Orthodontist (retired), 33 Cherryvalley Park, Belfast BT5 6PN N. Ireland marich@cvparkbt56pn.freeserve.co.uk
}

Gerald Brenan ${ }^{2}$ believed that pain could be overcome with the right philosophical attitude. 'At the same time one of my teeth began to ache and in the cold air this turned to neuralgia. I tried to tell myself that this was the supreme test and that if I failed to pass it I should be disgraced in my own eyes forever. But no arguments were strong enough.... These sentences explain fairly well my philosophy at this time, but they do not say how an itinerant knife grinder can be happy when he is starving, or even when it does not stop raining for a week. These were contingencies that needed to be fitted into my system and it was not long before I discovered how I must do this. My starting point was, I think, an experience I had had some time before at the dentist's. There were no injections of novocaine in those days, and twice every year I would spend an hour or two in the dentist's chair with a rubber gag in my mouth while Mr Peake drilled and drilled at some nerve-riddled cavity. Then one day I made an interesting discovery. Outside the window some clouds were scudding by and as I watched them, so far away, so free, so remote from the scene of my pain, I became aware of their peculiar beauty. It was a beauty of a different sort from that which I was familiar with, for it was purer and more detached from earthly things and at the same time, like a paradise I was forbidden to enter, it had a quality of pathos, I noticed too that as soon as the drill ceased to turn and the pain ebbed away, the clouds gradually became ordinary clouds again.

I do not know that I drew any particular deduction from this at the time, but gradually it became clear to me that certain states of exaltation may have to be paid for..... When I was young I reacted to boredom and inactivity as some people do to toothache -that is, with cries of rage and self-pity -whereas hardship brought out the best in me.

I am always astonished to find that one instantly becomes oblivious of the most acute pain if one has to concentrate on anything else, even on a triviality. While one concentrates on crossing a crowded street, in London, the consciousness of the torture of toothache or of being crossed in love is completely obliterated...'

Colin Middleton Murry's ${ }^{3}$ grandfather considered that philosophy could be employed to overcome other people's pain. 'He also had fixed ideas on health. These were very simple and could be summed up in the phrase: "All illness is imaginary." If he couldn't feel your pain, then you couldn't feel it either. It was a convenient creed in that it saved him unnecessary expense, but it didn't prevent my being driven almost distracted by the toothache. My only recourse when the pain became insufferable was to creep into the front parlour and crawl underneath the black sheepskin hearthrug.

One evening Grandma found me there curled up asleep and, without telling Grandpa, sneaked me off next morning to a dentist who pulled out the offending tooth. My fear that Grandpa might find out what we had done was almost worse than the pain had been.'

J. M. Synge ${ }^{4}$ noted a similar attitude to other people's pain among the Aran Islanders. 'Although these people are kindly towards each other and to their children, they have no feeling for the sufferings of animals, and little sympathy for pain when the person who feels it is not in danger. I 
have sometimes seen a girl writhing and howling with toothache while her mother sat at the other side of the fireplace pointing at her and laughing at her as if amused by the sight'.

V. S. Prichett's ${ }^{5}$ father blamed it all on imagination 'One evening, waiting for my father's return, she said she had toothache and called for brown paper and vinegar and made me warm it by the fire. Her face was swollen, she said, and when it was heated, she held the paper to her face. Father got home, grave and dignified. Mother went to the oven, banged down a plate of chops on the table and said: "There it is, eat it." "What is the matter with your face, old dear?" "You know what's the matter." "She's got toothache," we said. "Toothache?" said father. "What is that? Now, Beat, you know what I've been telling you. There is no such thing as toothache. You only think you've got it."

This interested us for Father said this in the kindest and most rational of voices and, in fact, Mother had said nothing about toothache earlier in the day. We were anxious for the discussion to be continued but we were sent to bed and then the nightly rumpus began again.'

It is unusual and probably unique to Julian Greene ${ }^{6}$ to find pleasure expressed as pain. 'At Andresy, I was so happy that my teeth ached. By that I mean certain moments when the joy of living swooped down on me, causing a horrible and delightful tickling in my molars that I have never been able to explain.'

\section{JUVENILE PAIN}

Childhood experiences of toothache left a lasting impression on Graham Greene ${ }^{7}$ 'Post-six too are my memories of being ill it happened often, but only the dentist left unhappy memories. Till now I had never suffered greater pain than I did then. I remember rolling on the drawing-room floor in agony from an exposed nerve. I don't think he was a very good dentist, and for years after I had left his care I would avoid walking, on the way to Northchurch and the Crooked Billet, past his house and the stained glass window representing the Laughing Cavalier which hid the chair of torture. Later I resented the fact that my parents used to visit a dentist in London$\mathrm{Mr}$ Crick, I felt sure, was as painless as he was expensive.

Remembrance of these experiences provided a somewhat drastic cure for boredom in later years 'Once on my free day I walked over the hills to Chesterfield and found a dentist. I described to him the symptoms, which I knew so well, of an abscess. He tapped a perfectly good tooth with his little mirror and I reacted in the correct way. "Better have it out," he advised.
"Yes," I said, "but with ether."

A few minutes unconsciousness was like a holiday from the world. I had lost a good tooth, but the boredom was for the time being dispersed.'

\section{TOOTHACHE IN THE TRENCHES}

First World War literature abounds with accounts of toothaches experienced on the battlefields of France. In that most famous memoir Goodbye To All That Robert Graves ${ }^{8}$ relates 'Then I got toothache which forced me to take a horse and ride twenty miles to the nearest army dental station at corps headquarters. I found the dentist under the weather, like everyone else. He would do nothing at first but grumble what a fool he'd been to offer his services to the King at such a low salary. "When I think," he complained, "of the terrible destruction to the nation's teeth now being done by unqualified men at home, and the huge fees that they extract for their wicked work, it makes me boil with rage." There followed further complaints against his treatment at headquarters, and the unwillingness of the R.A.M.C. to give dentists any promotion beyond lieutenant's rank. Later he examined my tooth. "An abscess," he said. "No good tinkering about with this; must pull it out." So he yanked at the tooth irritably, and the crown broke off. He tried again, damning the ineffective type of forceps which the Government supplied, found very little purchase, and broke off another piece. After half an hour he had dug the tooth out in sections. The local anaesthetic supplied by the Government seemed as ineffective as the forceps. I rode home with lacerated gums.'

The poet Edmund Blunden ${ }^{9}$ described his wartime dental experiences 'Long

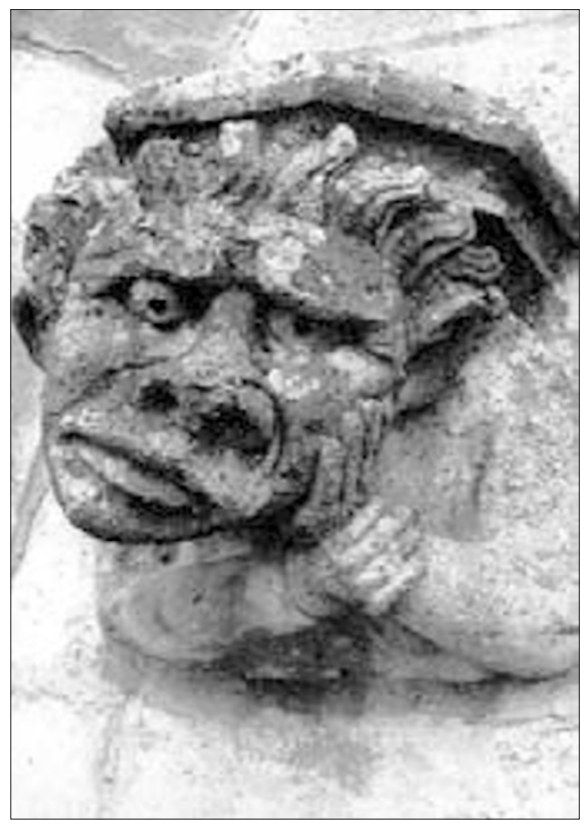

Gargoyle from unknown church in Southern France, 13th century (BDA Museum LDBDA C33)
"Toothache?" said father. "What is that? Now.... you know what I've been telling you. There is no such thing as toothache. You only think you've got it."

tramps day and night ruined my feet, but I had to walk to Poperinghe in great misery to have a tooth put to rest or die in the attempt. In daylight one might be unlucky over getting a lift on that hazardous road, which could be seen between its trees from the German and from our front line. I was. The tooth was pulled, back I went, and saw again the tipsy water-tower and the sole surviving pinnacle along the road through Ypres with illogical happiness. By the station I noticed some newly installed howitzers, and there was a suspicious quickness among those now passing out of Lille Gate, but even so, the dentist had been settled with.......... I could dilate upon other drama that occurred towards July 31, 1917; there was, for instance, that tooth of mine, which our Irish doctor painfully extracted for me by muscular Christianity in the wood, surely the last afternoon we were there; as many of my signallers as were off duty stood around with a hideous pleasure, and one or two begged to offer their compliments on so great a fortitude!'

The Irish poet and writer Monk Gibbon ${ }^{10}$ while serving in France '... began to suffer tortures from toothache. Watson mocked at my groanings and writhings, although I assured him he had been just as bad over his chilblains. Mosse, whom I was beginning to like greatly, was more sympathetic and departed down the road one night to fetch me oil of cloves from his billet. ........

Joy-rides were few, unless one could count a trip or two to the Canadian dentist at the hospital in the Citadelle in Doullens. Though he was in no way responsible for my unit he accepted me as a patient during my worst throes and afforded me some temporary alleviation.......

Our first halt was at Authie and our horses found themselves back on their old lines. I was once more in the throes of toothache, and, after the meal, made my way to the hospital in the chateau to beg a doctor there to take mercy on me and to remove the tooth. But the offending molar deceived him, just as it had deceived my Canadian friend at the Citadelle, and I was assured that it would be a 'great pity to take it out'. After a chat about Ireland and the gift of some aspirin, I returned to my billet 
and, with the help of Mosse's oil of cloves, managed to get a reasonable night ignorant of what torments still lay ahead of me........

Billets for the night varied greatly. After being in the saddle all day one welcomed a comfortable bed, but not infrequently this involved us in long arguments with some old woman. Oil of cloves had become useless for my toothache. If anything it seemed to aggravate it. I had read somewhere in a comic paper of standing on one's head as a remedy, and, in desperation one night, kneeling up in my sleeping bag, I lowered my head until I was more or less in the position advocated. The diary recorded my tortures.

Nearly went mad. Crying, praying. Stand on head, and it at last stops and I get to sleep. Late getting up next morning and across to breakfast. I indignant with Haines because no fish cakes for brekker......

After a further bout of agonising toothache while on trek, I rode into St.Venant to a field ambulance. This dentist also wanted to stop the tooth. But I declared that it had had its last chance. Out it came, after putting up a forceful resistance. It was 'a divil' according to the dentist; quite hollow below the surface of the gum, and on the point of forming an abscess. Looking into its cavernous depths, I could understand the agony which it had caused me.'

\section{GERIATRIC TOOTHACHE}

Toothache is perhaps less common in the octogenarian probably due to the fact that until after the second world war few octogenarians had many teeth left to ache. Anthony Burgess's ${ }^{11}$ hero in his novel Earthly Powers was an exception. 'It was the tooth that had begun to twinge at the Ovington's dinner party. It was now aching intolerably, and the gum above it was swollen and tender. The tooth itself was loose. An abscess, probably. Cognac quietened it, also some essence of cloves that Ali brought me from Grima or Borg the pharmacist, conveniently next door to my house, toothache was, I supposed, a kind of luxury to a man of my age. My father had been a dental surgeon; he had

\section{My father had been a \\ dental surgeon; he had \\ lectured his children on the}

importance of a healthy

dentition as other men

lectured theirs on the

importance of getting on in

the world or being discreet lectured his children on the importance of a healthy dentition as other men lectured theirs on the importance of getting on in the world or being discreet where they could not be moral. For all that I had never taken special care of my teeth, yet here I was in my eighty-second year with twenty-six of them, discoloured but sharp and sound, except for this rebellious premolar. I thought that even this might be saved, but could not risk going to a strange dentist, the waiting room full of aromatic Maltese, in Birkirkara or Valletta. I needed my regular dentist, Dr Pes, on the Piazza Bologna in Rome. Pes is a Sardinian name, less fitting for a dental surgeon perhaps than a pediatrician. A monied gentleman of my generation naturally kept faith with such tenders of his health, comfort and utilitarian needs as had proved their own faith in the metaphysics of skill and quality. Distance no object. Teeth in Rome, silk shirts in Kuala Lumpur, leather goods in Florence, tea in Mincing Lane. I had to go to Rome,.... Halfway home the bad tooth sang a forte measure of rage.'

\section{CURIOUS CURES}

Some interesting cures for toothache can be found in the pages of literature. Various folk remedies have been recommended for that troublesome primary toothache, infant teething. A good example occurs in Anthony Trollope's ${ }^{12}$ Barchester Towers. 'And then Miss Thorne was great about teeth. Little Johnny Bold had been troubled for the last few days with his first incipient masticator, and with that freemasonry that exists among ladies, Miss Thorne became aware of the fact before Eleanor had half finished her wing. The old lady prescribed at once a receipt which had been much in vogue in the young days of her grandmother, and warned Eleanor with solemn voice against the fallacies of modern medicine.

"Take his coral, my dear," said she, "and rub it well with carrot-juice: rub it till the juice dries on it, and then give it him to play with--"

"But he hasn't got a coral," said Eleanor.

"Not got a coral!" said Miss Thorne, with almost angry vehemence. "Not got a coral - how can you expect that he should cut his teeth? Have you got Daffy's Elixir?"

Eleanor explained that she had not. It had not been ordered by Mr Rerechild, the Barchester doctor whom she employed; and then the young mother mentioned some shockingly modern succedaneum, which Mr Rerechild's new lights had taught him to recommend.

Miss Thorne looked awfully severe. "Take care, my dear," she said "that man knows what he's about; take care he doesn't destroy your little boy. But"- and she softened into sorrow as she said it, and spoke more in pity than in anger- "but I don't know who there

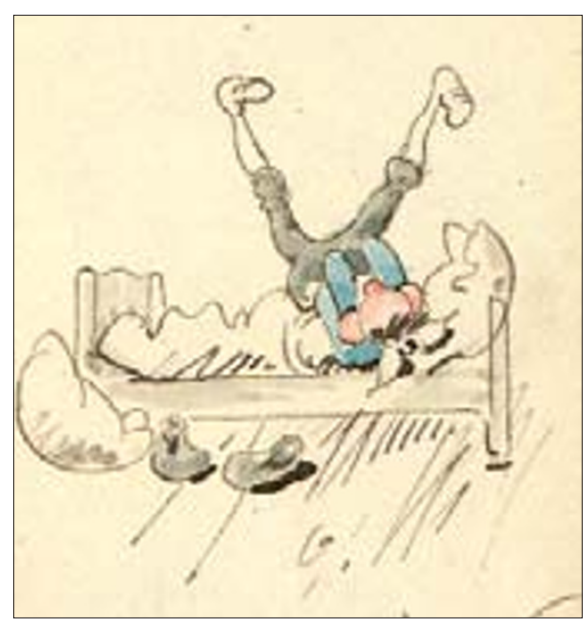

Image from Der Hohle Zahn (1868) [The Rotten Tooth] By Wilhelm Busch (1832 - 1908) Reprint Hannover 1987 (BDA Museum LDBDA

DB1989.192)

is in Barchester now that you can trust. Poor dear old Dr Bumpwell, indeed-"

"Why, Miss Thorne, he died when I was a little girl."

"Yes, my dear, he did, and an unfortunate day it was for Barchester. As to those young men that have come up since" (Mr Rerechild, by the bye, was quite as old as Miss Thorne herself), "one doesn't know where they came from or who they are, or whether they know anything about their business or not."

"I think there are very clever men in Barchester," said Eleanor.

"Perhaps there may be; only I don't know them; and it's admitted on all sides that medical men aren't now what they used to be. They used to be talented, observing, educated men. But now any whippersnapper out of an apothecary's shop can call himself a doctor. I believe no kind of education is now thought necessary."

Eleanor was herself the widow of a medical man, and felt a little inclined to resent all these hard sayings. But Miss Thorne was so essentially good-natured that it was impossible to resent anything she said. She therefore sipped her wine and finished her chicken.

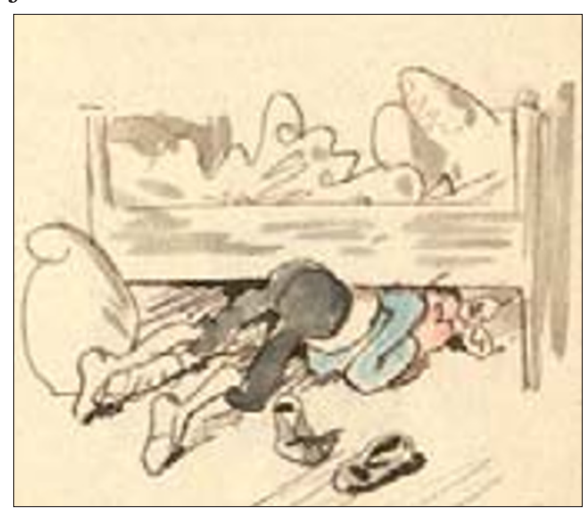

Images from Der Hohle Zahn (1868) [The Rotten Tooth]By Wilhelm Busch (1832 - 1908) Reprint Hannover 1987 (BDA Museum LDBDA DB1989.192) 


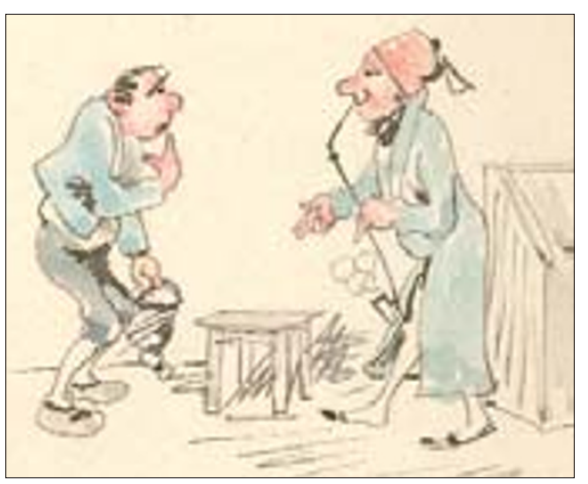

Image from Der Hohle Zahn (1868) [The Rotten Tooth] By Wilhelm Busch (1832 - 1908) Reprint Hannover 1987 (BDA Museum LDBDA DB1989.192)

"At any rate, my dear, don't forget the carrot-juice, and by all means get him a coral at once. My grandmother Thorne had the best teeth in the county, and carried them all to the grave with her at eighty. I have heard her say it was all the carrotjuice. She couldn't bear the Barchester doctors. Even poor old Dr Bumpwell didn't please her." It never occurred to Miss Thorne that some fifty years ago Dr Bumpwell was only a rising man, and therefore as much in need of character in the eyes of the then ladies of Ullathorne, as the present doctors were in her own.'

\section{MIND OVER MATTER}

Robert Morley ${ }^{13}$ claimed that 'Tooth worry is sometimes triggered by pain, when it is usually of a temporary nature and may subside after a visit to the dentist. If of this kind, you could follow Huw Weldon's maxim: "A toothache can often be cured by laying out a few old copies of Punch on your own dining-table."

Leonard Woolf' ${ }^{14}$ recommended 'Work is the most efficient anodyne - after death, sleep, or chloroform - for pain, whether the pain be in your great toe, your tooth, your head, or your heart.'

Count Vronsky in Tolstoy's ${ }^{15}$ Anna Karenina found an effective way of sublimating his dental pain :...he moved his jaw impatiently because of the incessant gnawing ache in his tooth which prevented him from even speaking with the expression he desired... He could hardly speak for the agonising pain in the big tooth which filled his mouth with saliva. He was silent, gazing at the wheels of the approaching tender gliding slowly and smoothly along the rails.

And all at once a different feeling, not an ache but a tormenting inner discomfort, made him for an instant forget his toothache. At the sight of the tender and the rails, and under the influence of the conversation with someone he had not met since the catastrophe, he suddenly recalled heras much as was left of her when he had rushed as one distraught into the railway shed and seen her mangled body, still warm with recent life, stretched out on a table shamelessly exposed to the gaze of all. The head, which had escaped hurt, with its heavy plaits and the curls about the temples, was thrown back, and the lovely face with its half-open red lips had frozen into a strange expression - pitiful on the lips and horrible in the fixed open eyes - as though she were repeating that fearful threat - that he would be sorry for it - that she had uttered at their last quarrel..... And he tried to remember her as she was when he met her the first time - also at a railway station mysterious, exquisite, loving, seeking and bestowing happiness, and not cruel and vindictive, as he remembered her at the last. He tried to recall his best moments with her but those moments were poisoned forever. He could only think of her as triumphant in having carried out her threat to inflict on him futile but ineffaceable remorse. He ceased to feel the pain in his tooth, and sobs distorted his face.'

V. S. Prichett ${ }^{5}$ employed his powers of concentration to overcome his toothache. 'I had toothache. I spent the day scrambling up a dry torrent-bed and then walked for miles in the pinewoods there and came down at some small posada to eat a poor thin garlic soup and two "pairs of eggs," as the Spaniards say. The light in the rough inn was too feeble for reading by; I had to share a room with three labourers and their wives, who kept the windows closed; and in the night my toothache was agony. I walked off the next day with a face blown up like a football. The heat was violent. The only diversion of the walk was half a mile of processional caterpillars as fat as my fingers, who were travelling up the road, head to tail. I killed a few; they joined up again and went on. I sat for hours in a small railway station until the Mixto came along. It took something like six hours to get to Madrid, shunting and unloading at every station.

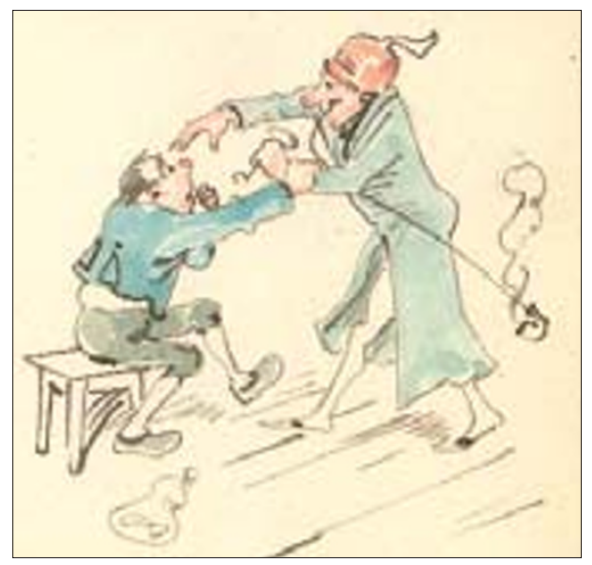

Image from Der Hohle Zahn (1868) [The Rotten Tooth] By Wilhelm Busch (1832 - 1908) Reprint Hannover 1987 (BDA Museum LDBDA DB1989.192)
So I read La Busca with desperate concentration to conquer the pain of the abscess. At last there was an explosion in my head. I spat out a foul liquid; the abscess had burst. I don't think I have ever read a novel with such care, looking up every strange word in the dictionary.'

Corbet Woodall's ${ }^{16}$ toothache miraculously disappeared when he discovered the alternative skills of a Tunisian dentist. 'Now one of the side-effects of the drugs I have been prescribed is that they have had an appalling effect on my teeth, several of which have had to be removed over the years.

\section{"A toothache can often be}

\section{cured by laying out a few \\ old copies of Punch on your own dining-table."}

It always starts with toothache, and this happened once when we were on holiday in Hammamat, Tunisia. We had arranged to share a taxi one day with some friends from the hotel to go into Tunis and see the remains of Carthage, which are beautifully preserved, and well worth seeing. The evening before, I contracted a really vicious toothache, and we reckoned on finding a dentist in the main street of Tunis, down which we drove the following day, my tooth giving me hell. Quite suddenly, my toothache disappeared as quickly as it had started. On the wall of a house, I had seen a large neon-lit sign, which read as follows; 'DENTAL SURGEON EXTRACTIONS AND CIRCUMCISIONS.' Incidentally, I still have that particular tooth, which has never given me any trouble since!'

\section{A CHARM AGAINST THE TOOTHACHE}

By the poet John Heath-Stubbs ${ }^{17}$

Venerable Mother Toothache

Climb down from the white battlements,

Stop twisting in your yellow fingers

The fourfold rope of nerves;

And to-morrow I will give you a tot of whisky

To hold in your cupped hands,

A garland of ainse-flowers,

And three cloves like nails.

And tell the attendant gnomes

It is time to knock off now,

To shoulder their little pick-axes,

Their cold-chisels and drills.

And you may mount by a silver ladder

Into the sky, to grind

In the cracked polished mortar

of the hollow moon.

By the lapse of warm waters,

And the poppies nodding like red coals,

The paths on the granite mountains,

And the plantation of my dreams. 


\section{AN OLD WIVES TALE}

E. M. Forster ${ }^{18}$ recounted a superstitious cure. 'Overhanging the house was an enormous wych elm and in its bark some white pig's teeth had been stuck. Yes, pig's teeth. They had been stuck in as a superstitious preventative against toothache. People would come and chew the bark and so obtain alleviation from their pangs. This had stopped in my day, and presently the bark grew over the teeth and hid them and finally the tree was cut down. But the house it overshadowed with its primitive magic still stands, and some of you may have guessed the house is Howards End.'

\section{SEDATION}

The minister's wife effectively cured George Birmingham ${ }^{19}$ of his toothache. 'She had before her marriage been trained as a hospital nurse, in those days quite a fashionable profession. Like many ladies, trained and untrained, she had a taste for amateur doctoring, and never shrank from a heroic remedy. I remember going to the rectory once to conduct a class for Sunday School teachers. I was suffering from raging toothache and told Mrs

Your trouble's in the jaw, you said?

\section{Come, let me just nip off} your head,

\section{And, when a new one}

\section{comes, the pain}

\section{Will never trouble you}

\section{again...}

Robinson that I feared the teachers would profit very little from my instruction that day. She undertook at once to set the matter right. This she did, not by extracting the tooth, though I do not think she would have shrunk from that if it had occurred to her as desirable, but by giving me a bottle of chloroform and ordering me to sniff at it till the pain stopped. The remedy was most effective. I ceased to suffer, but I do not know what the assembled Sunday School teachers thought of me. I went sound asleep before I had spoken ten sentences and was only awakened with the greatest difficulty.'

\section{DECAPITATION}

The most drastic cure of all was suffered by the poor perch in James Russell Lowell's ${ }^{20}$ poem.

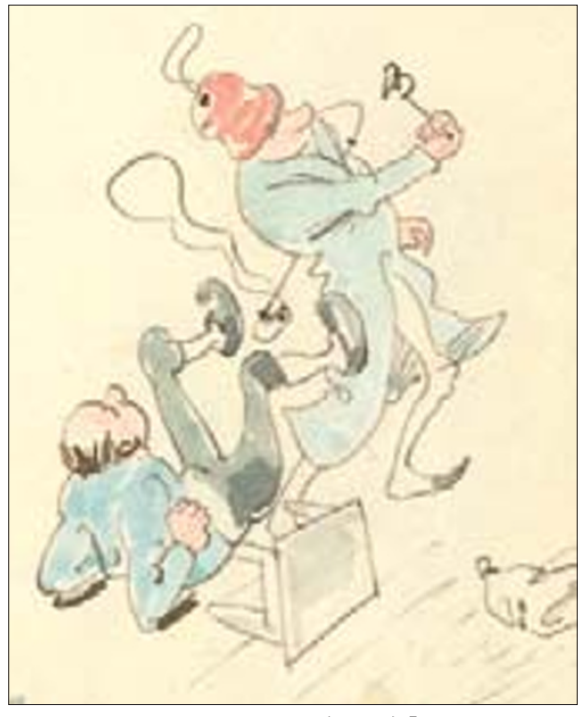

Image from Der Hohle Zahn (1868) [The Rotten Tooth] By Wilhelm Busch (1832 - 1908) Reprint Hannover 1987 (BDA Museum LDBDA DB1989.192)

\section{Doctor Lobster}

'A Perch, who had the toothache once Thus moan'd, like any human dunce: 'Why must great souls exhaust so soon Life's thin and unsubstantial boon? Existence on such sculpin termsTheir vulgar loves and hard-won wormsWhat is it all but dross to me, Whose nature craves a larger sea; Whose inches, six from head to tail, Enclose the spirit of a whale; Who, if great baits were still to win, By watchful eye and fearless fin Might with the Zodiac's awful twain Room for a third immortal gain? Better the crowd's unthinking planThe hook, the jerk, the frying- pan! o Death, thou ever roaming shark, Ingulf me in eternal dark!'

The speech was cut in two by flight: A real shark had come in sight; No metaphoric monster, one It soothes despair to call upon, But stealthy, sidelong, grim, I wis, A bit of downright Nemesis; While it recovered from the shock, Our fish took shelter 'neath a rock: This was an ancient lobster's house, A lobster of prodigious nous, So old that barnacles had spread Their white encampments o'er its headAnd of experience so stupend, His claws were blunted at the end, Turning life's iron pages o'er, That shut and can be oped no more.

Stretching a hospitable claw, 'At once' he said 'the point I saw; My dear young friend, your case I rue,
Your great, great, grandfather I knew; He was a tried and tender friend I know - I ate him in the end! In this vile sea a pilgrim long, Still my sight's good, my memory strong; The only sign that age is near Is a slight deafness in this ear; I understand your case as well As this my old familiar shell; This sorrow's a new-fangled notion, Come in since I first knew the ocean; We had no radicals, nor crimes, Nor lobster pots, in good old times; Your traps and nets and hooks we owe To Messieurs Louis Blanc and Co.; I say to all my sons and daughters, Shun Red Republican hot waters; No lobster ever cast his lot Among the reds, but went to pot: Your trouble's in the jaw, you said? Come, let me just nip off your head, And, when a new one comes, the pain Will never trouble you again:

Nay, nay fear naught: 'tis nature's law; Four times I've lost this starboard claw; And still, ere long, another grew, Good as the old - and better too!'

The perch consented, and next day An Osprey, marketing that way, Picked up a fish without a head, Floating with belly up, stone dead.

\section{Moral}

Sharp are the teeth of ancient saws, And sauce for goose is gander's sauce; But perches heads aren't lobster's claws.'

1. Maugham W S. The summing up. London: Wm Heinmann Pan, 1938.

2. Brenan G A. Life of One's Own. London: Hamish Hamilton Ltd, 1974.

3. Murry C M. One Hand Clapping. London: Victor Gollancz Ltd, 1975.

4. Synge J M. The Aran Islands. London: Allen and Unwin, 1934.

5. Prichett VS. A Cab at the Door. London: Chatto and Windus, 1968.

6. Greene J. The Greene Paradise. London: Marion Boyars, 1993.

7. Greene G. A Sort of Life. London: Bodley Head, 1971

8. Graves R. Goodbye to All That. London: Jonathan Cape, 1929.

9. Blunden E. Undertones of War. Middlesex: Penguin, 1973.

10. Gibbon M. Inglorious Soldier. London: Hutchinson, 1968.

11. Burgess A. Earthly Powers. London: Hutchinson and Co, 1980.

12. Trollope A. Barchester Towers. London: Collins, 1856

13. Morley R. Book of Worries. London: Weidenfeld and Nicolson, 1979.

14. Woolf L. The Journey not the Arrival Matters. London: Hogarth Press, 1969.

15. Tolstoy L N. Anna Karenin. Middlesex: Penguin, 1954.

16. Woodall C. A Disjointed Life. London: Wm Heinmann, 1980.

17. Heath-Stubbs J. A Charm against the toothache. London: Methuen \& Co, 1954.

18. Forster E M. The Hill of Devi. Middlesex: Penguin, 1983

19. Birmingham G. Pleasant Places. London: Wm Heinmann, 1934.

20. Lowell J R. Verse and Worse. London: Faber and Faber, 1958. 